\title{
PROTESTOS: UMA ANÁLISE LINGUÍSTICA EM MANCHETES ATRAVÉS DO PANORAMA DUCROTIANO
}

\section{PROTESTS: A LANGUAGE ANALYSIS OF HEADLINES BASED ON DUCROT}

\author{
Jane Kelly Silva de Lima*
}

\section{RESUMO}

Este artigo discorre sobre as marcas de pressuposição e de subentendido segundo a perspectiva de Oswaldo Ducrot, analisadas em duas manchetes de jornais (Jornal do Comércio e Folha de Pernambuco) sobre os protestos ocorridos no Brasil em junho de 2013, com o intuito de compreender as intencionalidades e sutilezas de sentidos que são atribuídos no enunciado. Concluímos com a pesquisa que as manchetes posicionam os sujeitos envolvidos no processo da enunciação dissimulando suas intenções.

Palavras - Chave: Pressuposição; Subentendido; Manchetes; Protestos.

\begin{abstract}
This article discusses presupposition and implicit marks from the perspective of Oswaldo Ducrot in two headlines about the protests that occurred in Brazil in June 2013(Jornal do Comércio and Folha de Pernambuco), in order to understand the intentions and subtleties of meaning that are assigned in the statement. The analysis demonstrates that the headlines position the subjects involved in the enunciation of the process disguising their intentions.
\end{abstract}

Keywords: Presupposition; Implicit; Headlines; Protests.

“Mestre em Ciências da Linguagem pela Universidade Católica de Pernambuco, UNICAP, Brasil. 


\section{Introdução}

A linguagem enquanto forma de ação ou interação pode ser tecida por uma gama de intenções dissimuladas, pois cada enunciado produzido na interação sustenta um ponto de vista, muitas vezes, estruturado de uma forma que parece não demonstrá-lo. Compreender uma enunciação é, pois, apreender essas intenções.

Diante disso, analisar um discurso não se resume em entender o que foi dito, é preciso perceber em que nível se inscreve a significação do enunciado produzido em determinados contextos, compreendendo o sentido explícito e implícito do enunciado. Uma vez que servimo-nos da língua para dizer o que temos desejo de externar, e estrategicamente construímos o modo como o discurso será apresentado para que consigamos nos eximir de certos conteúdos quando for conveniente. Uma estratégia muito utilizada nesse caso é o procedimento de implicitação ou simplesmente implícitos. Nas palavras de Ducrot (1977, p.13) implicitar é atender "[...] a necessidade de se dizerem certas coisas e de se poder fazer como se não as tivesse dito; de dizê-lo, mas de tal forma que se possa recusar a responsabilidade de tê-las dito".

Cabe aqui entendermos algumas definições apresentadas por Ducrot (1977) quanto aos conceitos principais de seus estudos. Segundo ele, a pressuposição é um tipo de implícito que emerge dos dados linguísticos e o subentendido é outro tipo de implícito que aflora das condições de produção do enunciado na dependência do contexto. $\mathrm{Na}$ ocorrência desses dois postulados estão presente o componente linguístico (os dados linguísticos) e o componente retórico (os dados linguísticos acrescido dos dados contextuais). Assim, concebe o sentido como um dado semântico que pertence ao nível do subentendido, e a significação como um dado semântico que se extrai do pressuposto. Contudo, essas definições mais a adiante foram reformuladas nos estudos ducrotiano, chegando à concepção de uma teoria polifônica da enunciação.

Assim, é importante atentarmos para a análise do discurso jornalístico uma vez que, como defini Fairclough (2001, p. 91) "o discurso é uma prática, não apenas de representação do mundo, mas de significação do mundo, constituindo e construindo o mundo em significado". Por isso, torna-se fundamental contemplar a notícia jornalística como gênero discursivo, que pode evidenciar os modos pelos quais as ideologias e as intenções permeiam o texto. Ao analisar o gênero textual "notícia jornalística", e/ou em específico a manchete, podemos conceber quais os mecanismos textuais que os jornais utilizam a fim de chamar a atenção do público-alvo. Pois, a manchete de um jornal é acima de tudo o primeiro turno de diálogo com o leitor, como apresenta Gra$\operatorname{dim}(2000$, p. 68), "os títulos anunciam o texto jornalístico que encabeçam, e são aquilo que em primeiro lugar o leitor apreende quando se debruça sobre as páginas de um jornal".

Isto não quer dizer que devemos desconsiderar a notícia completa, temos plena consciência que a leitura de um texto deve ser compreendida de forma a englobar todos os elementos que o compõem. Tentamos, contudo, fazer um recorte da composição estrutural do gênero, já que a leitura se inicia pelo título e o toma como propulsor. Ou até mesmo, como afirma Gradim (2000, p. 70), "os títulos, juntamente com as fotografias, são a primeira coisa, e por vezes a única, a que o leitor atenta no jornal. O título serve assim para informar, cativar, prender o leitor, despertando sua atenção e curiosidade".

Com isso, se pode acreditar que o modelo e a estrutura de um enunciado resultam em escolhas sobre o significado e construção de crenças, conhecimentos e relações sociais. Há um leque de possibilidades teóricas na análise de manchetes de jornal, consideramos o dito e o não dito nesse tipo de enunciado, como uma delas. Para tal, tomamos como base os estudos defendidos por Ducrot (1977, 1981, 1987) quanto à questão dos pressupostos e subentendidos, até a concepção da teoria polifônica, verificando em cada momento da trajetória a compreensão do autor sobre a maneira que os sentidos emergem do enunciado.

Dessa forma, temos como ponto de partida da pesquisa a seguinte indagação: Como as manchetes jornalísticas podem evidenciar diferentes sentidos para uma mesma notícia? Nossa hipótese é que o modo (dito ou não dito) como se apresenta as manchetes pode refletir as intenções e posicionamentos do que está sendo informando.

Em suma, a proposta dessa análise tem por objetivo compreender os possíveis meca- 
nismos textuais, conforme postula Ducrot, que o discurso jornalístico utiliza a fim de chamar a atenção de seu público-alvo, permitindo ao leitor captar sentidos e intenções que dialogam com os conhecimentos de mundo, valores ideológicos e morais.

\section{Pressupostos Teóricos}

Nos estudos sobre a pressuposição a contribuição de Ducrot $(1977,1981,1987)$ foi extremamente relevante. Seus trabalhos acorrem numa trajetória de significativas transformações que envolvem tanto o aspecto semântico quanto o aspecto pragmático da concepção de língua/linguagem. Uma das noções semânticas que Ducrot $(1977,1981,1987)$ procura desenvolver com mais ênfase em sua teoria é a noção de pressuposição Para tanto, vai sustentar uma abordagem estruturalista e lógico semântico- pragmática do fenômeno da pressuposição, desenvolvendo de modo sistemático concepções específicas e semanticamente fundamentais, tais como, implícito, pressuposto e subentendido, dentre outras questões.

Em termos de significação Ducrot (1978) apresenta os níveis em que se dá o sentido do discurso. Tendo o explícito e implícito subjacente às intenções que locutor revela no processo comunicativo. Afirma que a significação explícita é observável na estrutura gramatical no sentido restrito, e a significação implícita é mais sutil, podendo dissimular as intenções do falante. Desse modo, desvinculará os pressupostos das condições de verdade e defenderá o pressuposto e o subentendido como duas formas de implícito Essa concepção denominada implicação ou implicitação estabelece três formas de implícitos (KOCH, 2011, p. 27):

a) Implícito baseado na enunciação - se digo: está calor aqui dentro, para indicar que desejo que abram a janela (subentendido).

b) Implícito baseado no enunciado - João veio me procurar, logo deve estar em situação difícil (inferência).

c) Implícito do enunciado - algo intermediário entre o dizer e o não dizer, que constitui uma forma de significação contida de modo implícito no enunciado (pressuposto), em oposição àquilo que é posto.

O autor apresenta alguns conceitos basilares dos procedimentos de implicitação, tais como: o enunciado que consiste em uma realização e a enunciação que vem a ser um evento constituído pela produção de um enunciado, isto é, pela realização de uma frase. Define ainda a pressuposição como um tipo de implícito que surge a partir dos dados linguísticos e o subentendido como outro tipo de implícito que nasce das condições de produção do enunciado, ou seja, no contexto. Implicitar passa a ser também um modo de agir, com isso, o autor instaura o quadro discursivo e chega à conclusão de que a pressuposição está no jogo de fala, integrando dessa forma a pragmática à semântica.

Procurando depreender e descrever o fenômeno pressuposicional, Ducrot (1977) propõe realizar uma descrição partindo exclusivamente do dado linguístico. Nessa visão se instaura dois elementos: componente linguístico (os dados linguísticos) e componente retórico (os dados linguísticos acrescidos dos dados contextuais), o primeiro cuidaria de apreender os dados semântico-linguísticos e estabelecer um sentido, diga-se, literal. Já o segundo seria responsável por desdobrar os sentidos tendo em vista o contexto criado; seria a parte da semântica que se encontra integrada aos dados pragmáticos. Assim, Ducrot (1977) formula uma descrição semântica que vai além da superfície linguística. Colocando o pressuposto como um dado que se extrai estritamente da língua (componente linguístico), atribuindo o pressuposto ao sentido e o subentendido, por sua vez, refere-se ao que se pode extrair da língua de acordo com o contexto (Componente retórico), isso se atrela à significação. Assim, essa teoria poderia ser representada pelo esquema seguinte:

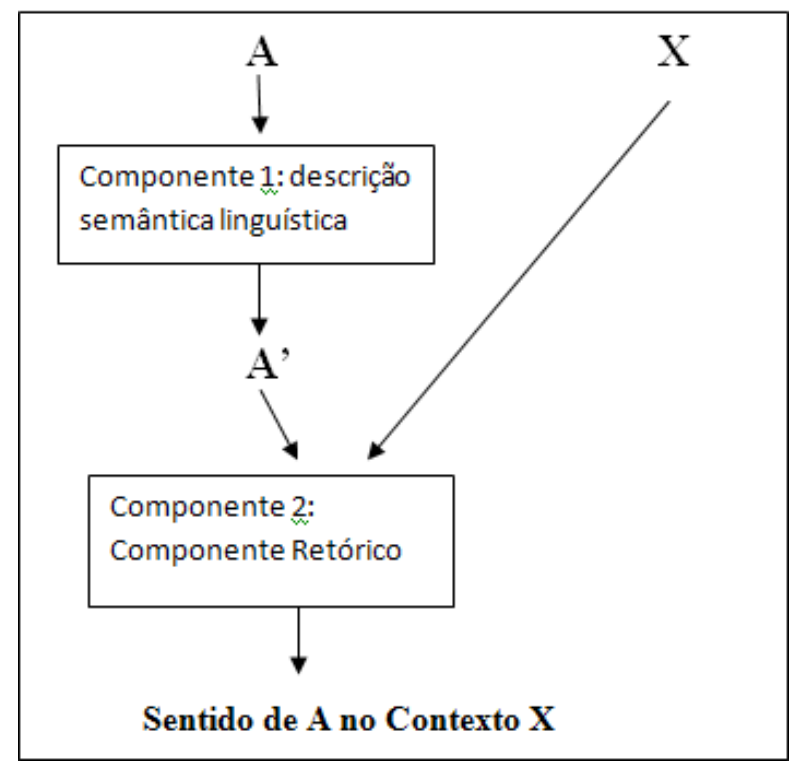


O esquema acima desenhado deve ser analisado por duas direções. Uma em que consiste o primeiro componente, ou melhor, um conjunto de conhecimentos (descrição semântica linguística de L ou, simplesmente, componente linguístico) nesse caso tem-se para cada enunciado independente de qualquer contexto certa significação (A corresponde a significação A'). A segunda direção levaria a análise do segundo componente (o componente retórico), este atrelado ao contexto (A' ligada a A e as circunstâncias $\mathrm{X}$ nas quais $\mathrm{A}$ é produzido, caso que a significação efetiva de A está em X). Em síntese: a significação (A') de um enunciado (A) depende do contexto (X) em que produzido.

Para análise do componente linguístico, tomam-se em princípio os enunciados como ponto de partida, destituídos do contexto. Uma significação é dada aos enunciados tendo por base a pressuposição, quer dizer, os pressupostos são depreendidos da língua. Analisando o componente retórico, tem-se uma significação dos dados linguísticos atrelada ao contexto, isto é, o subentendido é depreendido do linguístico pelo contexto enunciativo. Nesse momento de sua teoria Ducrot (1977) relaciona à pressuposição ao componente linguístico, e o subentendido ao componente retórico, a fim de estabelecer as relações lógico-semântica-pragmáticas, defendendo que existem formas de dizer as quais se denominam implícitos e que não se encontram propriamente na superfície linguística, mas que vêm marcados nela. Todavia, esse raciocínio das noções de pressuposto e subentendido passará por algumas reformulações no pensamento ducrotiano.

Ducrot (1987) passa reformular questões relativas à noção de pressuposição, descrevendo-a como um tipo particular de ato ilocucionário, de modo a renunciar a oposição estabelecida entre pressuposto e subentendido pela lei do encadeamento. Assim, novas definições surgem para a pressuposição e para o subentendido. Pressuposição de um enunciado seriam as indicações que ele traz à margem de uma linha argumentativa do discurso e o subentendido a maneira pela qual esse sentido deve ser decifrado pelo destinatário. No entanto, encadeia-se por meio do posto: "Se uma frase pressupõe X e um enunciado dessa frase é utilizado em um encadeamento discursivo, por exemplo, quando se argumenta a partir dele, encadeia-se com o que é posto e não com o que é pressuposto". Ducrot conclui, então, que o valor ilocucionário de um enunciado pode não estar marcado na frase, assim a pressuposição como ato ilocucionário pode aparecer no nível do enunciado como forma de um subentendido. A noção de subentendido remete a um processo particular de codificação e decodificação.

Utilizando essa noção de encadeamento, torna-se possível determinar o que é posto e o que é pressuposto num enunciado. Verificando os mecanismos pelos quais se pode realizar a descrição semântica dos atos de enunciação, tais como os critérios da negação, da interrogação, da exclamação, do encadeamento lógico do discurso, Vogt (1989, p. 31) ressalta que:

Qualquer que seja a significação de um enunciado com pressuposto, ela, para ser explicada deverá antes do trabalho do C.R levar em conta, ao nível do C.L, o estabelecimento e a distinção da pressuposição e da posição de um enunciado. [...] é necessário que a D.S. de uma língua leve em conta o modo pelo qual estes dois elementos participam da constituição do sentido de um enunciado, bem como a anterioridade do pressuposto em relação ao posto.

Por esse aspecto é necessário atentar a descrição semântica em dois níveis de análise: o nível do sentido e o nível da significação. Representando esse processo de compreensão do enunciado, temos:

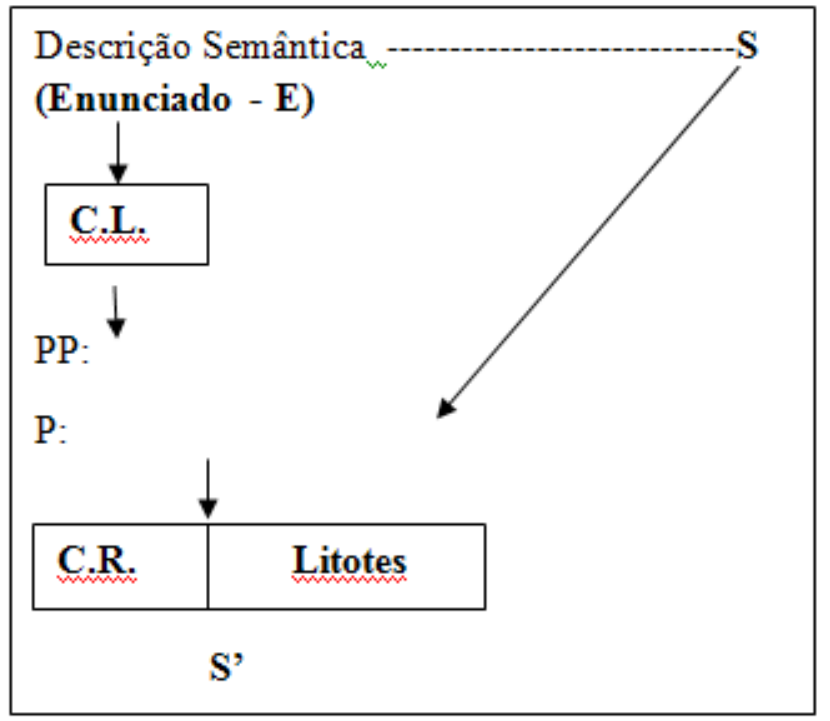

Suponhamos que um locutor $\mathrm{A}$, dirige um enunciado (E) a um interlocutor B, este interprete tal enunciado com determinada significação (S'). Quais seriam, na verdade, os mecanismos capazes de ex- 
plicar a produção dessa significação (S')? O enunciado (E) contém partes integrantes de seu conteúdo linguístico, ou seja, um posto (P) e um pressuposto (PP), levando-se em conta que tal enunciado (E) é produzido por A numa situação específica $(\mathrm{S})$, tendo o interlocutor B conhecimento dessa mesma situação interpretará a significação (S'). Metodologicamente, a produção da significação (S') passa primeiro pelo sentido literal do enunciado (E), isto é, pela distinção dos dois elementos que constituem o sentido do enunciado levando em conta a anterioridade do elemento pressuposto em relação ao elemento posto, para, então, ao nível do C.R., através da litotes, chegar à significação desejada.

Por fim, Ducrot (1987) trará os postulados da pressuposição tomados à Polifonia da Enunciação. A pressuposição passa a ser vista como um ato ilocucionário que possibilita um desdobramento do enunciador e do destinatário. Reitera o pressuposto e o subentendido como duas formas de implícito, no entanto, com novos posicionamentos de que não se constituem como opostos, mas constituem-se como dois estatutos que se interpenetram. Nesse caso, implicitar passa ser visto como uma forma de se utilizar dos dados linguísticos para fazer falar o que não se pretende dizer diretamente. Embora, reestruture algumas vertentes da implicitação ainda relaciona o pressuposto à frase e o subentendido ao enunciado, com a possibilidade de fazer com que o pressuposto finalmente se integre aos dados pragmáticos por meio do expediente de subentender.

Nesse novo conceito, a pressuposição é encarada como ato ilocucionário que pode fazer falar as muitas vozes presentes num determinado discurso. Existem determinadas formas linguísticas que funcionam como índices, no discurso, da presença de outras vozes. A significação se encontra no que está linguisticamente posto, assim, o pressuposto e o subentendido ficam instaurados na produção desse enunciado.

Para compreendermos de forma mais prática os postulados teóricos defendidos por Ducrot, de que os sentidos e intenções podem ser enunciados não limitadamente na superfície textual, mas além dela, tomemos como corpus desta pesquisa o gênero notícia, mais precisamente um dos elementos de sua composição estrutural: a manchete. Que não deixa de desempenhar um papel fundamental na constru- ção de sentidos. Ao estudarmos os títulos de notícias jornalísticas, as manchetes, podemos perceber as sutilezas da dimensão discursiva existentes no campo dialógico desse gênero textual.

Dentre todas as manchetes que compõem uma capa de jornal, existe uma que recebe um destaque maior, pela relevância de sua notícia. Por isso, as manchetes jornalísticas apresentam-se na primeira folha dos jornais. Destacadas pela fonte, pelo layout, pelas imagens e até mesmo pelo enunciado. Segundo o Manual de Redação e Estilo (2005, p. 57) de O Globo, a manchete trata-se do título principal dando maior relevância, ou seja, tem como função apresentar as notícias mais importantes do jornal, encontra-se na primeira página, ou são manchete dos cadernos, seções ou páginas na extensão do jornal.

O título e/ou manchete tem um valor importante, pois é a primeira incitação da leitura de um texto à construção de seus sentidos.

\section{Metodologia}

Esse estudo apresenta uma revisão bibliográfica dos estudos acerca dos pressupostos, subentendidos, encadeamentos e polifonia, pela perspectiva de Oswaldo Ducrot $(1977,1981,1987)$, analisados no discurso jornalístico de duas manchetes de jornais Folha de Pernambuco e Jornal do Comércio, com o propósito de compreender os possíveis mecanismos textuais, postulados por Ducrot, que faz com que a enunciação possa ter uma multiplicidade de significações, atentar para uma enunciação é, pois, apreender as intenções de quem fala.

Por isso, para esta proposta optou-se pelo discurso jornalístico, especificamente para as notícias jornalísticas com ênfase nas manchetes, pois elas apresentam os acontecimentos segundo a visão de mundo e a ideologia dos seus produtores, quer dizer, no processo de produção da manchete além das informações serem postas com efeito de objetividade a fim de chamar a atenção de seu público-alvo, orienta as marcas do enunciado que permiti o leitor captar sentidos e intenções que dialogam com os conhecimentos de mundo, valores ideológicos e morais.

Pode-se dizer que é característico do leitor o hábito de folhear de título em título a procura de algo que lhe chame a atenção, que seja adequado aos seus interesses e propósitos, e então, a partir 
desse foco prossiga a leitura do texto. Nesse sentido, Gradim (2000, p. 68-69) afirma que "nenhum jornalista desconhece a importância da arte de titular e, também, as dificuldades que a construção de um bom título apresenta". Isso nos faz acreditar que já no próprio enunciado da manchete os mecanismos textuais, expressos ou implícitos, posicionam o sujeito enunciador.

Assim, as manchetes coletadas pertencem a dois dos principais jornais do nosso estado, Pernambuco, (Jornal do Comércio e Folha de Pernambuco) que circulam em diferentes segmentos sociais, e que foram comercializados na data do dia 18 de junho de 2013 tendo como tema os protestos - recentes até aquele momento - ocorridos em diversas capitais do Brasil. Ambos destacaram a notícia que manifestantes, assim chamados, caminharam até a cúpula do Congresso Nacional para reivindicar as injustiças sofridas, como também, relataram que milhares de brasileiros em diferentes capitais do Brasil se uniram pelas mesmas motivações.

O corpus desta pesquisa foi analisado de acordo com as posições de Ducrot ao longo de suas sucessivas revisões, nas quais a noção de pressuposição, subentendido, encenação e polifonia passam a exercer um papel fundamental no momento da enunciação, em que é preciso compreender a direção e o sentido orientado pelo enunciado para traduzir as intencionalidades na produção do texto.

Portanto, as manchetes receberam sob a luz do panorama ducrotiano um olhar analítico em suas construções linguísticas, que julgamos não suficiente em si mesmo, mas relevante aos estudos da linguagem, do discurso e da enunciação.

\section{Análise do Corpus}

Tornemos dizer que todo e qualquer discurso carrega consigo as intencionalidades de quem o produz (KOCH, 2011), todavia, nem sempre as intenções se apresentarão de modo explícito no texto. Com base no panorama ducrotiano revisado, pode-se compreender os efeitos de sentidos marcados, ou não, no enunciado. Busquemos entender essa perspectiva teórica analisando o corpus coletado nas diferentes modalidades em que Ducrot consegue identificar e conceituar o posicionamento do enunciador.
Reiteramos que ambos os jornais tratam de um mesmo tema: os protestos ocorridos no país em junho de 2013. Concebemos ainda, que se tratando de um gênero multimodal vários elementos colaboram para a interpretação dos fatos, deste a imagem, cores, disposição gráfica do texto, até as informações sutis da produção da notícia. Faremos para essa análise, no entanto, um recorte dentre a composição estrutural do gênero notícia, focalizando a manchete principal elaborada por cada um deles sobre o tema abordado.

Segundo Fairclough (2008, p. 104) "as pessoas fazem escolhas sobre o modelo e a estrutura de suas orações que resultam em escolhas sobre o significado (e a construção) de identidades sociais, relações sociais e conhecimento e crença". Nesse caso, os enunciados posicionam os sujeitos, tanto os que produzem quanto aqueles para quem são dirigidos. Assim, temos as seguintes manchetes:

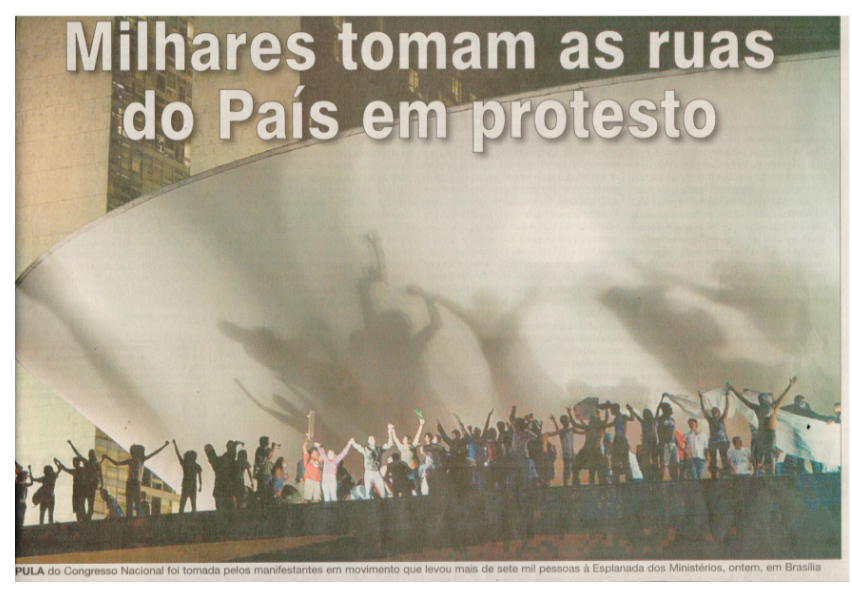

Folha de Pernambuco em 18/06/13

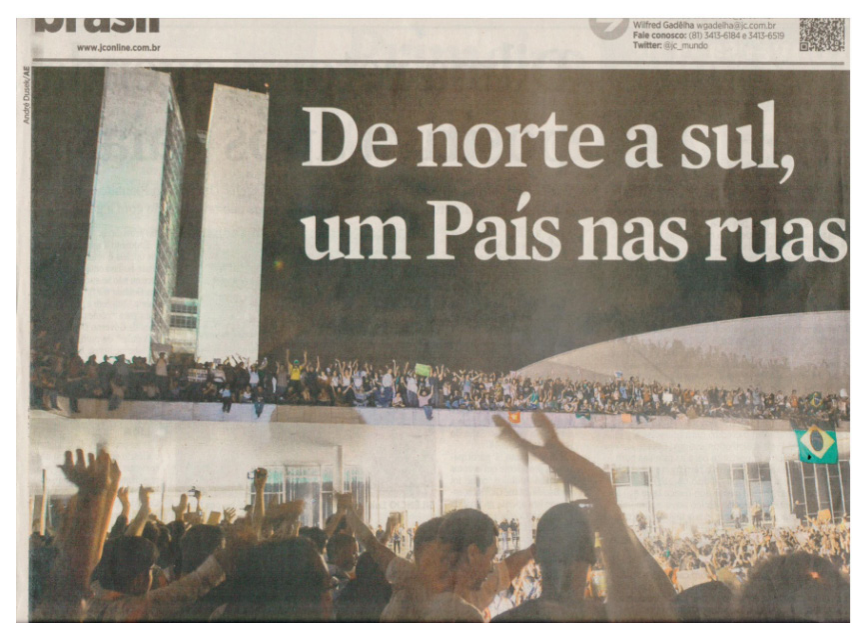

(Jornal do Comércio em 18/06/13) 
Analisamos as peças em cada etapa da trajetória dos estudos de Ducrot $(1977,1981,1987)$, com o intuito de compreender as perspectivas teóricas reformuladas pelo autor na concepção de que todo o discurso possui marcas que podem evidenciar as intenções de quem o produz, seja por uma teoria de argumentatividade na língua, ou mesmo, por uma teoria polifônica.

Em primeiro momento, as manchetes foram analisadas mediante uma descrição semântica linguística, temos, então, o esquema abaixo:

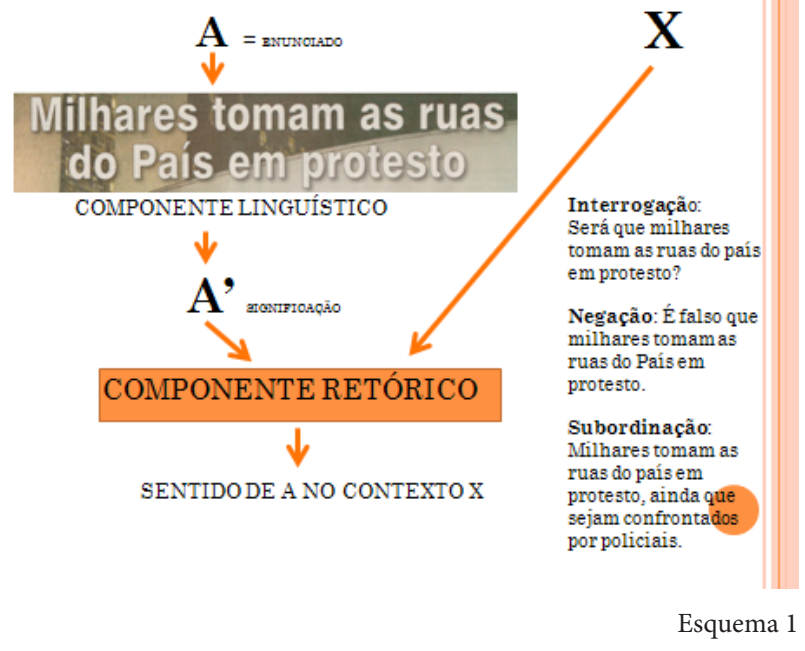

Nessa fase da teoria de Ducrot, há o postulado básico que o componente linguístico e o componente retórico definem o processo de significação. Em tese, pode-se considerar que o esquema acima é dividido em dois compartimentos principais: um componente linguístico - C.L. e um componente retórico - C.R. Na organização desta forma de descrição semântica, o enunciado A "Milhares tomam as ruas do país em protesto", receberá uma significação A' "Cidadãos estão indo às ruas protestar", o resultado dessa significação, porém, se atrela às condições de produção do enunciado, ou seja, o contexto $\mathbf{X}$ "o aumento das passagens, a corrupção, os gastos nas construções de estádios, revoltaram a população que decidiu expor a insatisfação mediante protestos".

Visto dessa forma, a manchete orienta a alcançar certas conclusões a partir do sentido presente na própria estrutura lexical. Essa perspectiva procura mostrar que, muitas vezes, as frases possuem argumentatividade, ou seja, o valor argumentativo das palavras é o responsável pela direção do discurso.
Assim, o sentido pressuposto no enunciado A: " $\mathrm{Mi}$ lhares tomam as ruas do país em protestos" por meio de seus itens lexicais dentro do aparato retórico orienta às intenções do enunciador de querer argumentar, por exemplo, que o povo está insatisfeito e caminham em sinal de protesto, ou, que o povo tomou uma atitude diante da má situação. Neste exemplo, o dito está evidenciado no próprio componente linguístico.

Em contraste, as intenções argumentativas construídas pelo subentendido finge esconder o posicionamento do enunciador. Vejamos a outra manchete pelo esquema abaixo:

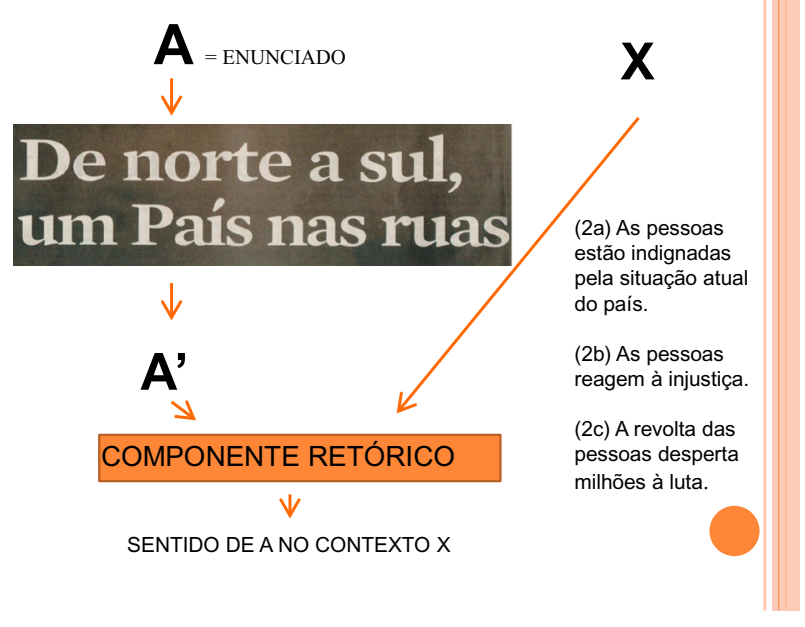

Esquema 2

Neste exemplo, o componente retórico é o responsável para reinterpretar os sentidos do componente linguístico. $\mathrm{O}$ subentendido versa aquilo que é dito dentro de um contexto $\mathbf{X}$, é crucial na descrição semântica linguística os componentes atuarem juntos para apreender a orientação argumentativa do enunciador.

No esquema, o sentido do enunciado $\mathbf{A}$ " $D e$ norte a sul, um País nas ruas”, depende não apenas do Componente Linguístico, mas também do Componente Retórico. De modo que, o contexto $\mathbf{X}$ (o aumento das passagens, a corrupção, os gastos nas construções de estádios, a revolta da população que decidiu expor a insatisfação mediante protestos) é quem determinada o sentido "Cidadãos estão indo às ruas protestar", e a significação A' "As pessoas estão indignadas pela situação atual do país”. 
Desse modo, a significação A' "Os Cidadãos estão insatisfeito e vão às ruas protestar" está subentendida no enunciado A "De norte a sul, um País nas ruas" mediante o contexto da enunciação. O componente retórico transfere reciprocamente ao componente linguístico os sentidos atribuídos no enunciado, permitindo o leitor subentender o que está sendo dito dentro de um determinado contexto. Isso denuncia a intencionalidade do enunciador em querer afirmar $\mathbf{A}$ ' pelo sentido de $\mathbf{A}$ no contexto $\mathbf{X}$.

$\mathrm{Na}$ verdade, segundo a perspectiva de Ducrot (1987) tem-se uma diferença entre as indicações de significação nos dois esquemas, as quais são denominadas de pressupostos (esquema 1) e subentendidos (esquema 2). Um primeiro critério que permite esta classificação deriva do comportamento muito particular assumido pelos pressupostos no momento em que o enunciado que os veicula é submetido a certas modificações sintáticas, tais como a negação ou a interrogação. $\mathrm{O}$ autor mostra que os pressupostos de um enunciado continuam a ser afirmados pela negação deste enunciado ou por sua transformação em pergunta.

Assim, o enunciado do esquema 1 "Milhares tomam as ruas do país em protesto" mantém seu pressuposto (Cidadãos estão protestando) em todas as ocorrências sintáticas: Interrogação: Será que milhares tomam as ruas do país em protesto? Negação: É falso que milhares tomam as ruas do País em protesto; Subordinação: Milhares tomam as ruas do país em protesto, ainda que sejam confrontados por policiais. O elo de subordinação no enunciado citado não se refere ao elemento pressuposto, mas apenas ao resto do conteúdo denominado de conteúdo posto.

Esse critério de transformação sintática já não funciona com os subentendidos. Uma vez que o fenômeno de pressuposição parece estar em estreita relação com as construções sintáticas gerais, o que permite tratá-lo no componente linguístico, ao passo que esse mesmo critério não pode ser empregado aos subentendidos, pois a relação com a sintaxe é bem mais difícil de aparecer, sendo previstos por um componente retórico que leva em conta as circunstâncias da enunciação.

Através desta distinção, basta colocar na origem dos subentendidos um procedimento discursivo que considere não apenas o próprio enunciado, mas sua enunciação, ou seja, o fato de que o enunciado é utilizado em um momento determinado em circunstâncias específicas. Retomando o esquema 2, pode-se analisar como o C.R. é fundamental na construção do sentido. A título de exemplo, o enunciado $\mathbf{A}$ "De norte a sul, um País nas ruas" produzido em duas situações diversas, a saber:

$\mathbf{X}^{\mathbf{1}}$ : O locutor de $\mathbf{A}$ profere esse enunciado ao assistir a transmissão televisiva da festividade do Carnaval no país.

$\mathbf{X}^{2}$ : O locutor de $\mathbf{A}$ profere esse enunciado ao assistir a transmissão televisiva dos protestos no país.

A descrição semântica formulada por Ducrot (1987) explica a produção, a partir do mesmo enunciado A "De norte a sul, um País nas ruas" duas significação A' diferentes:

Em $\mathbf{X}^{\mathbf{1}}: \mathbf{A}^{\prime}$ - O povo está alegre.

Em $\mathbf{X}^{2}: \mathbf{A}^{\prime \prime}-$ O povo está revoltado.

Assim, para captar a intenção proposta no enunciado A (De norte a sul, um País nas ruas) de que o povo está revoltado com a situação do país, é preciso entender que o componente linguístico da descrição semântica funciona em parceria indissociável com o componente retórico para a construção de uma significação. Tendo em vista que, o subentendido só toma seu valor particular ao opor-se a um sentido literal do qual ele mesmo se exclui. A significação A' ou A" apresentada no exemplo anterior, só pode ser extraída quando a partir de um C.L. inserido em um C.R., restringe o momento da enunciação, quer dizer, através das situações específicas em que o enunciado é produzido.

Em síntese, esse modelo de descrição semântica proposto por Ducrot, conferi um estatuto radicalmente diferente ao pressuposto e ao subentendido. Em que o primeiro ligado ao próprio enunciado, bem como aos fenômenos sintáticos gerais, é produto do componente linguístico. O segundo, por sua vez, resulta de uma reflexão do destinatário sobre as circunstâncias de enunciação da mensagem.

Contudo, como foi abordado anteriormente, Ducrot passa a introduzir uma série de modificações relativas às questões das relações entre pressupostos e subentendidos. Segundo Koch (2011, p. 59): 
Nessa nova formulação, a pressuposição se defini, basicamente, pela lei do encadeamento: só se encadeia sobre o posto, sendo a informação pressuposta apresentada não como o tema do discurso ulterior, mas apenas como o quadro no qual ele irá se desenvolver. A noção de subentendido passa a ser reservada para designar os efeitos de sentido, aqueles que surgem na interpretação [...]

Utilizando a noção de encadeamento, torna-se possível determinar o que é posto e o que é pressuposto num enunciado. Se uma frase pressupõe $\mathrm{X}$ e um enunciado dessa frase é utilizado em um encadeamento discursivo, por exemplo, quando se argumenta a partir dele encadeia-se com o que é posto e não com o que é pressuposto Ducrot (1987).

No segundo momento de sua teoria, o autor reformula alguns conceitos básicos, sem abandonar a perspectiva de que o discurso é impregnado por intenções implícitas ou explícitas refletidas no enunciado. É possível analisar as manchetes segundo a nova abordagem apresentada por Ducrot, na tentativa de conhecer os modos em que os posicionamentos dos sujeitos da enunciação são postos no enunciado. Retornemos, pois, as manchetes:

(1)

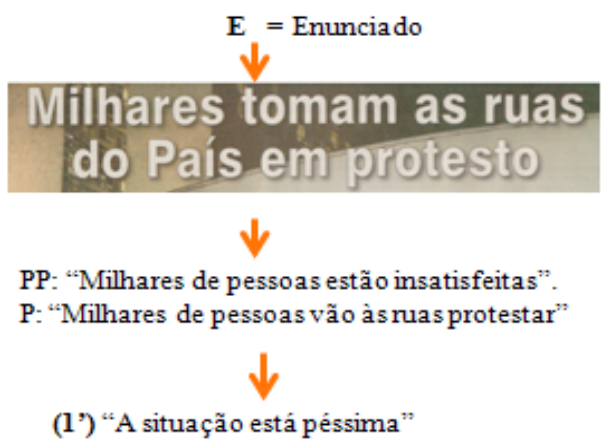

Nesse aspecto, a pressuposição aparece como uma tática argumentativa dos interlocutores. Dizer que o enunciado "Milhares tomam as ruas do País em protesto" pressupõe: "Milhares de pessoas estão insatisfeitas" é fazer com que o destinatário admita o pressuposto pela fala do locutor, já que a informação pressuposta é colocada à margem do discurso, sem que por isso seja dado o direto ao destinatário de prosseguir o diálogo a respeito da informação pressuposta.

Essa noção de pressuposição traz as indicações que um enunciado pode afirmar coisas sem que pareça estar afirmando permitindo o locutor de se eximir de sua responsabilidade, uma vez que pode haver pressuposições subentendidas. Apreender a significação 1' que a situação está péssima a partir do enunciado Milhares tomam as ruas do País em protesto, é compreender que as intenções argumentativas são veladas no próprio enunciado. Se compreendermos que o subentendido está ligado ao modo como este sentido é manifestado, captaremos que o locutor apresenta sua fala como um enigma que cabe ao destinatário, por exemplo, concluir a significação 1" "A situação está péssima".

Da mesma forma, a segunda manchete permite afirmar certos posicionamentos que parecem não estar dito no enunciado. Verifiquemos:

(2)

$$
\mathbf{E}=\text { Enunciado }
$$

\section{De norte a sul, \\ um País nas ruas}

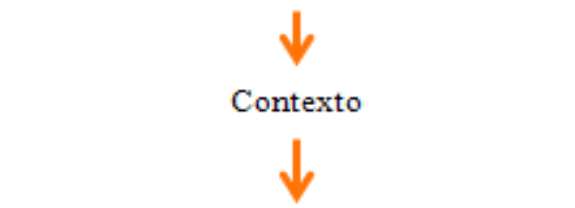

PP: Os cida dãos foram às ruas expor suas insatisfações. P: Em todo o país os cidadãos estão nas ruas.

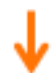

2'A insatisfação atingi a maioria da população.

O locutor deixa a cargo do destinatário a construção do sentido 2" "A insatisfação atingi a maioria da população" pois, o subentendido diz respeito à maneira pela qual o sentido deve ser interpretado pelo destinatário. Ducrot apresenta esse fenômeno como o "retrato" da enunciação em que o locutor se distancia da responsabilidade pelo viés do subentendido.

A construção de $\mathbf{E}$ "De norte a sul, um país nas ruas" é formulada para subentender 2" "A insatisfação atingi a maioria da população”. No entanto, toda astúcia do procedimento consiste em que o locutor pode continuar apoiando sua argumentação sobre o próprio conteúdo da informação dada por meio de um encadeamento. "É esse processo que ilustra o subentendido: para dizer alguma coisa, faz-se o ou- 
tro dizer o que se disse" (Ducrot, 1987, p. 43).

Em síntese, as manchetes se analisadas por essa abordagem são construídas para apontar uma orientação argumentativa de sentidos e significações, contudo, de maneira a deixar o leitor pressupor ou subentender aquilo que na verdade está camuflado no que é dito. Mais uma vez, as marcas presentes no enunciado colaboram para desvendar as intencionalidades discursivas.

Apesar de conseguir demonstrar através desses novos conceitos como as intenções são mascaradas no enunciado, Ducrot aperfeiçoa sua teoria permitindo entender as sutilezas do processo de enunciação.

No terceiro momento desse panorama, Ducrot (1987) aprofunda as questões relativas aos expedientes de implicitação e reitera um pouco mais o direcionamento enunciativo, engendrando a Teoria Polifônica da Enunciação. Defini de enunciador a pessoa a quem é atribuída a responsabilidade de um ato ilocucionário, e destinatário a pessoa a quem este ato se destina, e não corresponde necessariamente com o locutor e o alocutário. A pressuposição, se encarada como ato ilocucionário, pode fazer falar as muitas vozes presentes num determinado discurso. Assim, nota-se que:

\section{Withares tomam as ruas do País em protesto}

(1) - (Folha de Pernambuco em $18 / 06 / 13)$

\section{De norte a sul, um Pais nas ruas}

(2)- (Jornal do Comércio em $18 / 06 / 13)$
No enunciado (1) "Milhares tomam as ruas do País em protesto" em uma análise pressuposicional distingue:

PP: "Milhares de pessoas estão insatisfeitas";

P: "Milhares de pessoas vão às ruas protestar".

Embora se tenha um locutor $\mathbf{L}$ único, trata-se de dois atos de asserção atribuídos a enunciadores diferentes. Neste caso, o conteúdo pressuposto dado pela asserção "Milhares de pessoas estão insatisfeitas" quem afirma não é simplesmente o locutor $\mathbf{L}$, mas uma comunidade linguística que pode ser a opinião geral. A condição para que haja polifonia é, portanto, que o Locutor $\mathbf{L}$ seja diferente do enunciador $\mathbf{L}$ '.

No interior do enunciado (1) "Milhares tomam as ruas do País em protesto" percebe-se a voz do Lo- cutor L "milhares de pessoas vão às ruas protestar" e uma outra voz, a do enunciador $\mathbf{L}$ " "milhares de pessoas estão insatisfeitas".

Nesse jogo de representações as intenções são mascaradas dentro do próprio discurso, o sentido da manchete "Milhares tomam as ruas do País em protesto" é concebido simultaneamente por uma multiplicidade de vozes diferentes da do locutor. Quando, por exemplo, os leitores dessa manchete interpretar a significação como "a situação do país chegou ao limite", passam a ser também enunciadores, de forma que, mesmo o locutor sendo único o sentido da manchete não é atribuído apenas a ele, mas, constituído pelas relações interpessoais que se estabelecem no processo da enunciação, e que faz explodir uma pluralidade de vozes.

Da mesma forma, o enunciado (2) "De norte a sul, um País nas ruas" trazendo:

PP: Os cidadãos foram às ruas expor suas insatisfações contra o governo.

P: Em todo o país os cidadãos estão nas ruas.

No processo de enunciação dessa manchete é possível perceber a incorporação no discurso de L (P: Em todo o país os cidadãos estão nas ruas) uma asserção atribuída a outro enunciador L1 (PP: Os cidadãos foram às ruas expor suas insatisfações contra o governo). O que levaria a um encadeamento possível: "A insatisfação atingi a maioria da população". Desse modo, quem afirma que a população está insatisfeita não é apenas o locutor, mas uma comunidade linguística formada pelo enunciador e o destinatário.

Por essa perspectiva da polifonia tem-se um posicionamento resguardado, pois o locutor só se responsabiliza e se identifica como enunciador daquilo que é posto, no nosso exemplo, P: Em todo o país os cidadãos estão nas ruas, distinto do enunciador do PP: Os cidadãos foram às ruas expor suas insatisfações contra o governo. Assim, pela natureza do implícito as intenções do falante ganham força e se misturam as vozes de opinião geral da encenação discursiva.

Enfim, as análises dessas manchetes através do panorama ducrotiano das marcas linguísticas de pressuposição, subentendido, encadeamento e polifonia mostraram que em cada etapa dos estudos de $\mathrm{O}$. Ducrot há um terreno bastante fértil a ser explorado, 
e que embora apresentando sucessivas revisões em suas perspectivas teóricas, o autor consegue sustentar a concepção de que os atos linguísticos são dotados de intencionalidades que orientam a determinadas opiniões, mesmo que, muitas vezes, se insinuem como ingênuos. Todavia, as implicações percebidas no discurso reafirmam as sutilezas e intenções do falante/enunciador.

\section{CONSIDERAÇÕES FINAIS}

Em suma, o percurso do panorama ducrotiano a respeito dos mecanismos linguísticos ativados na produção do discurso no que diz respeito às intencionalidades do falante, esclarece que as relações que se estabelecem entre o enunciado e a enunciação possuem caráter semântico, pragmático e ideológico. Os enunciados trazem em sua estrutura relações de ordem semântica-pragmática que revelam dentro do próprio discurso o posicionamento e intenções do enunciador.

As marcas das intenções, explícitas ou veladas, que o texto veicula, consideravelmente evidenciam a posicionamento dos enunciadores do discurso. Nas palavras de Fairclough (2008, p. 68):

Os enunciados posicionam os sujeitos - aqueles que os produzem, mas também para aqueles para quem são dirigidos, de modo que descrever uma formulação como enunciado não consiste em analisar a relação entre o autor e o que ele diz (ou quis dizer, ou disse sem querer), mas em determinar que posição pode e deve ser ocupada por qualquer indivíduo para que ele seja o sujeito dela.

Desse modo, ao considerarmos que a manchete é, acima de tudo, o primeiro contato que o leitor tem com a notícia, teremos convicção que a escolha do título é ancorada por marcas linguísticas que posicionam os sujeitos envolvidos no processo da enunciação. E qual seria o motivo que leva o enunciador de uma manchete mascarar ou explicitar suas intenções? Isto é algo que pode ser levado para novas pesquisas. No momento, porém, compreendemos com base nas análises aqui desenvolvidas que o discurso jornalístico utiliza diferentes mecanismos linguísticos, como a pressuposição, o subentendido, a encenação discursiva, para apresentar as informações ao público-alvo de modo a dissimular a intencionalidade discursiva.
Os sentidos evidenciados nas manchetes são apreendidos através do que é dito e do que não é dito na estrutura linguística do enunciado. A manchete construída pela Folha de Pernambuco (Milhares tomam as ruas do País em protesto), como vimos, se apresenta pela noção de pressuposição. Há um posicionamento mais declarado ao se deixar pressupor que "a situação está péssima" pela própria materialidade do enunciado. Diferentemente da manchete produzida pelo Jornal do Comércio, ancorada pelo viés do subentendido, evidenciando um posicionamento resguardado, deixando ao destinatário a responsabilidade de subentender que "o povo está insatisfeito com o governo".

Ademais, as discussões apresentadas nesta pesquisa resgatam a contribuição de Ducrot (1977, 1981, 1987) em vista de uma perspectiva teórica importante na análise linguística do discurso jornalístico, que esta discussão trouxe como foco as manchetes de jornais, destacando entre outros fatores as intenções do falante/enunciador.

\section{REFERÊNCIAS}

DUCROT, Oswald. Princípios de Linguística Semântica: dizer e não dizer. Trad.Rodolfo Ilari, Carlos Vogt, Rosa Attié Figueira. São Paulo: Cultrix, 1977.

O dizer e o dito. Trad. Eduardo Guimarães. Campinas, SP: Pontes, 1987.

A pragmática e o estudo semântico da língua.

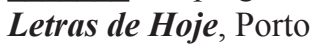

Alegre, v. 40, n. 1, p. 9-21, mar. 2005.

FAIRCLOUGH, Norman. Discurso e mudança social. Brasíla: Editora UnB, 2008.

GRADIM, Anabela. Manual de Jornalismo. Covilhã / Portugal: Universidade da Beira Interior, 2000.

$\mathrm{KOCH}$, Ingedore Villaça Grünfeld. Introdução à Lingüística Textual: trajetória e

Grandes Temas. São Paulo: Martins Fontes, 2006.

Contexto, 2004.

A inter- ação pela linguagem. São Paulo: Contexto, 1984

Argumentação e Linguagem. São Paulo:

MOURA, Heronides Maurílio de Melo. Significação e Contexto: uma introdução a questões de semântica e pragmática. Florianópolis: Insular, 2006. 
VOGT, Carlos. Linguagem, Pragmática e Ideologia. São

Paulo: Editora HUCITEC, 1989.

O intervalo semântico. São Paulo: Ática, 1977.

ECO, Umberto. A estrutura Ausente. 7 ed. São Paulo: Editora Perspectiva, 1991. 